\title{
高炉低還元材比操業を模擬した二次元コールデルによる 固体不安定降下挙動の解析
}

\author{
高橋 洋志* ·河合 秀樹* · 小林 基史* · 福井 俊史*
}

Two Dimensional Cold Model Study on Unstable Solid Descending Motion and Control in Blast Furnace Operation with Low Reducing Agents Rate

Hiroshi Takahashi, Hideki KaWai, Motofumi Kobayashi and Toshifumi Fukui

Synopsis : Unsteady behavior with bridging/slipping of solid bed in low reducing agents operation of blast furnace was simulated using a two dimensional cold model. Alumina sphere was used as representative particle of coke/ore packed bed. Two kinds of deadman particles different in gas permeability was examined. To simulate the effect of cohesive zone on unsteady behavior, a sand layer of lower gas-permeability was charged with a certain thickness at the top of the bed, which descended with a form of cohesive zone when it reached at the lower part. Further, a fine coke layer was set at the shaft bottom with a certain size assuming accumulation of fines. Unsteady phenomenon with the fine coke accumulation was also observed with another thin sand layers, charged in the shaft assuming increase of gas-permeability resistance in reducing coke supply operation. It was revealed that the ratio of peripherally flowing rate of tuyere gas had a considerable effect on the discontinuous behavior of both solid descending motion and gas static pressure. The ratio increased with decline in deadman gas-permeability, approach of the simulated cohesive zone to deadman surface and inflow of small particles into raceway. There was a lowest critical position of the simulated cohesive zone for the rapid increase of discontinuity. The bridging/slipping behavior with fines accumulation was significantly affected by the low gas-permeability layers charged in shaft. Setting up the chimney zone of high gas-permeability at the central part was effective to decrease the discontinuous motion.

Key words : blast furnace; low reducing agents; moving bed; solid flow; unstable solid behavior; bridging; slipping.

\section{1. 緒言}

棚品やスリップで代表される固体の不安定挙動は炉頂 コークス荲装入割合の縮減により一層顕著になるものと考 えられている。この様な低還元材比操業では通常操業に比 ベて軟化融着带はより炉下方に形成され，その結果，炉芯 と融等带の間のいわゆるコークスファンネルフロー領域の 流路幅が縮小し、棚吊・スリップ現象はこの流路幅縮小と 深く関係すると考えられている ${ }^{1,2)}$ 。羽口から観察した火 炎の輝度も周期的に变動し2)，これはコークスまたはコー クス・鉄鉱不混合物のレースウエイへの流入が周期的であ ることを示唆している。特に炉芯の通気抵抗が大きい場合 には，流路幅が狭く，かつ流路の長いコークスファンネル フロー領域を透過するためのガスの流体抵抗は増大する。 これがレースウエイへのコークスのスムーズな流入を妨げ るものと考えられる。コークス装入割合の減少による融着 䒠のコークススリット幅の減少もコークスファンネルフ ロー領域のガス通気抵抗を一層増加させる原因となる。

·お，コークス装入割合を縮減した操業下では，鉄鉱石，
コークスの交互供給で形成される鉱不・コークス混合領域 の体積割合も増大する。従って, 空間率の大きいコークス 層の減少と空間率の小さい混合領域の増加により，シャフ 卜部を透過するガスの通気抵抗は増大するであろう。大量 のガスが炉下部で発生した時は, 空間率の大きい壁部に 添ってガス流が上昇し，ガスが炉頂に達した時点での炉頂

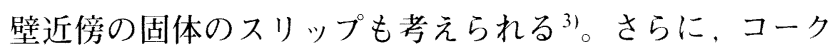
スの降下中にはその機械的破壊により大量のコークス粉の 発生が考えられる。これはコークスに対する化学反応の負 荷増大により強度の弱い多孔質コークがより多く生成され るためである。小島ら ${ }^{4}$ は高炉の解体研究を行い粉コーク スはシャフト中間レベルからレースウエイの領域に分布す ると述べている。館ら ${ }^{5}$ は熱間モデル笑験で燃焼領域周り の粉コークスの蓄積が炉況不安定の原因であると述べてい る。

本研究の目的は, 上述の背景の下, 灯頂コークス装入割 合を縮減した操作における棚吊・スリップを含む充填層の 不安定挙動を高炉二次元冷間モデルを用いて実験的に模擬 することにある。基本粒子よりも通気抵抗の大きい粒子層

愿学榆文: ISIJ Int., Vol. 45 (2005), No. 10, pp. 1386-1395

米成18年.4川21 I受付半成 18 年. 6 月 12 日受理 (Received on Apr. 21, 2006; Accepted on June 12, 2006; orignially published in 1SIJ Int., Vol. 45, 2005, No. 10, pp. 1386 - 1395)

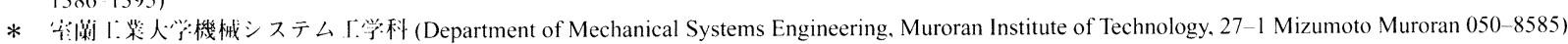


を，炉頂にて一定厚みで水平充填すると，水平層は炉下部 に至ってはあたかも融着帯に類似した形状で降下する。こ の擬似融着带を利用して，充填層の不安定降下挙動に与え るコークスファンネルフロー領域の流路幅（擬似融着帯と 炉芯の間の距離）の影響を評価した。さらに，シャフト部 の通気抵抗を増加させた状況を作り，その上でシャフト下 端に粉コークス層を初期充填（粉コークスの蓄積を模擬） した操作を行い，固体流れ挙動に与える粉蓄積層の影響を 調べた。また，一般に固体粉のレースウエイへの流入は羽 ロガスのレースウエイ奥（充填層内部）への透過を妨げる 要因になるであろうとの観点から，粉コークスのレースウ エイへの流入と固体の不安定挙動の関係も調べた。

\section{2. 実験}

透明アクリル樹脂板からなる二次元モデル（左半分モデ ル）をFig. 1に示す。レースウエイでのコークスの消費は 装置背面に $45^{\circ}$ で取り付けた $\phi 38$ のパイプから粒子を抜き 出すことで模擬した。粒子の排出流量は密閉箱内の電磁 フィーダーによって制御した。垂直壁側に取り付けたサブ パイプからも粒子を小流量で抜き出し炉芯高さをこの粒子 抜き出しレベルで一定に保った。羽口として内径 $0.9 \mathrm{~cm}$ の パイプ，4本を一七ットとしてボッシュ下部に取り付けた。 羽口深度 $=0$ の時, レースウエイはより垂直方向に膨張し 粒子の不連続排出を伴う不安定挙動を起こしやすい6)。不 安定炉況下ではこれに類似の状況で操作されるものと想定 して，本実験では羽口深度 $=0$ を採用した。空気は室温で 供給し，炉頂より排出した。密閉箱内で粒子排出操作を 行っているので空気の下方流れは起こらない。粒子の降下 速度はフルード数に関する相似則を用いて決定した7)。ガ 又速度は，固体の不安定挙動を明瞭に捕らえるため，相似 則から推定された速度の 2.5 3 倍に設定した。用いた粒子 の物性を Table 1 に示した。粒子径 $2.6 \mathrm{~mm}$ のアルミナ球を 鉱石・コークス充填層を代表する粒子として用いた。アル ミナ粒子は炉頂周辺(Fig. 1, A)に3 分每に間欠的に供給し た。固体排出の期間，レーザー変位センサーにより降下す る粒子層表面とセンサーの間の距離を，また，ガス静圧， ベリー壁での固体左力及び粒子フローパターンを測定し た。測定個所を Fig. 1に示す。以下に示す二種類の実験を 行った。

\section{$2 \cdot 1$ 実験 1}

擬似融着帯と炉芯表面間のコークスファンネルフロー領 域の流路幅及びレースウエイに混入する細粒が固体の不安 定流れに及ぼす影響を調べる実験。アルミナ粒子の流れが 定常に達した後，炉頂から 15 20 cm の位置に，通気抵抗 の大きい“砂粒子層”を厚さ $10 \mathrm{~cm}$ で水平にフルスパン充 填した（Fig. 3(a) 参照）。Table 1に示す砂 A, 砂Bおよび砂 $(\mathrm{A}+\mathrm{C})$ を砂層として用いた。砂 $(\mathrm{A}+\mathrm{C})$ は体積比で（砂 $\mathrm{A}$

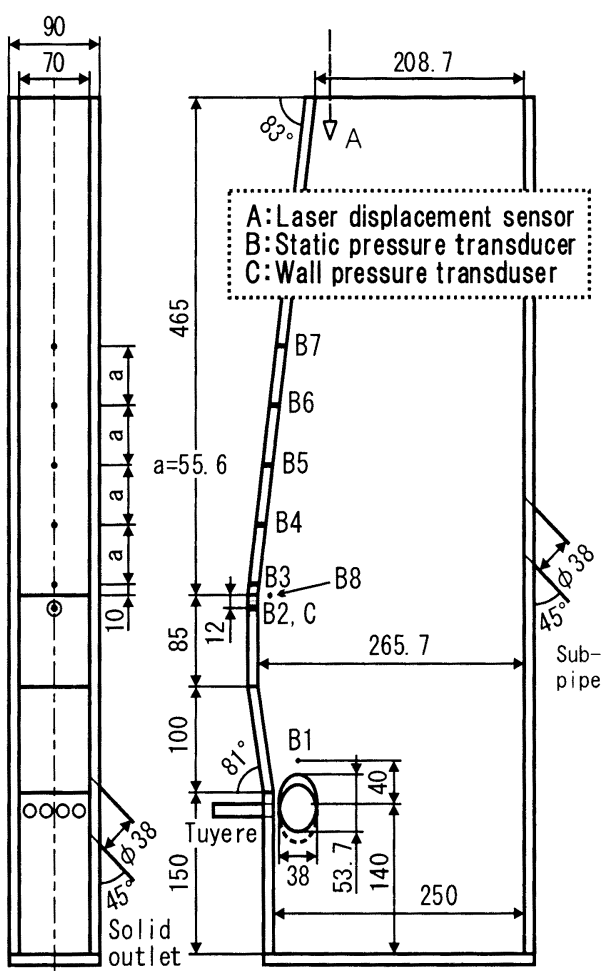

Fig. 1. Two-dimensional apparatus.

Table 1. Physical properties of particles.

\begin{tabular}{|c|c|c|c|c|c|c|c|}
\hline & \multirow{2}{*}{ Material } & \multirow{2}{*}{$\begin{array}{c}\text { Alumina } \\
\text { sphere }\end{array}$} & \multicolumn{4}{|c|}{ Sand } & \multirow{2}{*}{$\begin{array}{l}\text { Fine } \\
\text { coke }\end{array}$} \\
\hline & & & A & B & $\mathrm{C}$ & $A+C$ & \\
\hline$d_{p}$ & {$[\mathrm{~mm}]$} & 2.6 & 1.9 & 1.2 & 0.6 & - & 0.55 \\
\hline$\rho_{p}$ & {$\left[\mathrm{~kg} / \mathrm{m}^{3}\right]$} & - & 2600 & 2590 & 2615 & - & - \\
\hline$\rho_{b}$ & {$\left[\mathrm{~kg} / \mathrm{m}^{3}\right]$} & 870 & 1350 & 1345 & 1455 & - & 671 \\
\hline $\mathcal{E}$ & {$[-]$} & 0.48 & 0.48 & 0.48 & 0.44 & 0.45 & $0.51^{*}$ \\
\hline$u_{m f} f^{*}$ & {$[\mathrm{~m} / \mathrm{s}]$} & 1.02 & 0.976 & 0.732 & 0.335 & - & 0.224 \\
\hline$\varphi^{* *}$ & {$[-]$} & 1.0 & 0.6 & 0.7 & 0.9 & - & 0.8 \\
\hline$\theta$ & {$\left[{ }^{\circ}\right]$} & 29 & 41 & 37 & 37 & - & 40 \\
\hline$f_{1}^{* * *}$ & {$\left[\mathrm{~N} \cdot \mathrm{s} / \mathrm{m}^{4}\right]$} & 1822 & 5102 & 9398 & 34240 & - & 25355 \\
\hline$f_{2}^{* * *}$ & {$\left[\mathrm{~N} \cdot \mathrm{s}^{2} / \mathrm{m}^{5}\right]$} & 6344 & 8690 & 11794 & 25650 & - & 17689 \\
\hline
\end{tabular}

砂C）=7/3の混合物である。砂層を充填した後, アルミナ 粒子を炉頂まで周辺供給し，その後アルミナ粒子の供給無 しで3分間粒子を排出降下させた。この後再度アルミナ粒 子を炉頂まで周辺供給する。この操作を 4 5回（通算 12 分〜15 分間の流動）繰り返した。水平砂層は降下と共に炉 下部で融着帯に類似した形状となる。ただし，砂層の通気 抵抗と実炉融着帯の通気抵抗に関しては気体と固体間相万。 運動の相似性は考慮していない。

以上の操作で形成される炉芯（アルミナ球）以外に，人 為的に通気抵抗の大きい砂 $\mathrm{A} て ゙$ 炉芯を形成した奏験も行つ た。これは，低還元材比操業下で形成される炉芯コークス の粒子径はより小さくなること，および炉芯表面に粉コ一 クスが蓄積されること等により炉芯通気抵抗がより增加す ることを想定した実験である。砂 A炉芯はアルミナ粋子灯i 
芯と间一形状になるよう調整した。

さらに，不完全水平充填層すなわち Fig. 10右壁（垂直 壁）から $5 \mathrm{~cm}$ または $10 \mathrm{~cm}$ の部分は砂層非充填領域とした 実験も行った。砂層非充填領域はアルミナ粒子で充填した。 アルミナ粒子層のガス透過性は砂層よりも高いのでガスは このアルミナ粒子層領域を透過しやすい。換言すると，ガ ス流路のチムニー効果（煙突効果）を期待した実験である。 な抢，エルガン式から計算した流体抗力に関する係数 $f_{1}, f_{2}$ をTable 1に示した（エルガン式のUはガス空等速度であ る)。なお，実験 1 では全ての条件で羽口速度は $U_{B}=40 \mathrm{~m} / \mathrm{s}$ で一定とし，静圧はタップB1で測定した。

\section{$2 \cdot 2$ 実験 2}

シャフト下端に粉コークスを初期充填し，粉コークスの 局所蓄積を模擬した実験。粉コークスのシャフト下端への 初期装人は粉コークスの炉内分布に関する小島ら ${ }^{40}$ の報告 を参考にした。粉コークス層の厚みは $5 \mathrm{~mm}$ と $15 \mathrm{~mm}$ ，幅 はシャフト壁から $40,80,160 \mathrm{~mm}$ 打よび右壁（垂直壁）ま でのフルスパンとした。また、コークス装入割合を縮減し た操業で出現するシャフト通気性の低下を模擬するため, シャフト部に厚さ $5 \mathrm{~mm}$ の砂 $\mathrm{B}$ 三層， $5 \mathrm{~cm}$ 間隔でアルミ ナ粘子と父互に充填して低通気性領域を作った。この場合 も尖炈とデルの流動に関する相似則は考慮していない。 灯頂表面の変位とべリー部からシャフトでのガス静压を測 定した。

充填粒子間の空間を通過する粉コークス粒子の輸送に関 する考察》に基づき，三種類のガス速度を選んだ。アルミ 十粉子屏の充填構造として, 空間率が近い值を持つ等球の 規則立方配列 $(\varepsilon=0.476)$ を仮定した。単一細粒（粉粒子） に働く流体抗力を $F_{D}$, 外力を $F_{E}$ とすると, $F_{E}>F_{D}$ なら細 粘に作用する外力が流体抗力に勝るのでアルミナ粒子間隙 を落下する。この考えを規則立方充填配列の最狭窄部に適 用して単一細粒に働く力のバランスからガス速度を定め た。即ち, シャフト下端レベルで, 羽口速度 $U_{B}=35 \mathrm{~m} / \mathrm{s}$ の とき $F_{D}>F_{l:}, U_{B}=28 \mathrm{~m} / \mathrm{s}$ のとき $F_{D}<F_{E}, U_{B}=31 \mathrm{~m} / \mathrm{s}$ は上記の 中間の条件に対応する。一般に, $F_{D}>F_{E}$ の条件で細粒は粗 粒子間を上昇することができ(これを細粒のフラディング と呼ぶ），一方， $F_{D}<F_{F}$ では細粒は粗粒子と共に降下する であろう。Table 2 に実験 1 ，実験 2 の実験条件を示した。

\section{3. 実験結果と考察}

\section{$3 \cdot 1$ 実験 1}

小頂表面の変位の変化状況から粒子群は停止と滑りを繰 り返しながら降下することがわかった。この不連続運動は 本装置ではレースウエイの膨張と収縮挙動と完全に対応し ていた。灯頂粒子はレースウエイが膨張している間は静止 状態にあり、レースウエイの収縮，即ち崩壊と共に降下し た。実験1で得られた炉頂変位の特性を棚吊/スリップの周
Table 2. Experimental conditions.

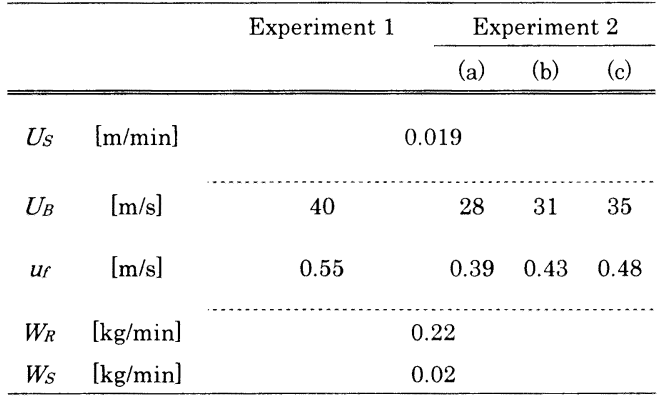

Table 3. Result of Experiment $1\left(U_{B}=40 \mathrm{~m} / \mathrm{s}\right)$.

\begin{tabular}{|c|c|c|c|c|c|}
\hline \multirow[t]{2}{*}{$\begin{array}{l}\text { Run } \\
\text { No }\end{array}$} & \multirow[t]{2}{*}{$\begin{array}{c}\text { Material of } \\
\text { horizontal layer }\end{array}$} & \multirow[t]{2}{*}{$\begin{array}{c}\text { Deadman } \\
\text { material }\end{array}$} & \multirow{2}{*}{$\begin{array}{c}\text { Run time } \\
\text { [min] }\end{array}$} & \multirow{2}{*}{$\begin{array}{c}\text { Bridging } \\
\text { /slipping } \\
\text { frequency } \\
\text { [s] }\end{array}$} & \multirow{2}{*}{$\begin{array}{c}\text { Slipping } \\
\text { distance } \\
{[\mathrm{mm}]}\end{array}$} \\
\hline & & & & & \\
\hline $1-1$ & $\operatorname{Non}\left(U_{B}=0\right)^{*}$ & Alumina** & $0 \sim 12$ & $0 \sim 0.2$ & $0.05 \sim 0.2$ \\
\hline $1-2$ & Non & Alumina & $0 \sim 12$ & $1.5 \sim 2.5$ & $0.5 \sim 1$ \\
\hline $1-3$ & Non & Sand A & $0 \sim 12$ & $8 \sim 15$ & $5 \sim 7$ \\
\hline \multirow[t]{2}{*}{$1 \cdot 4$} & Sand A & Alumina & $0 \sim 10.5$ & $1.5 \sim 3$ & $0.5 \sim 2$ \\
\hline & $(15 \sim 25 \mathrm{~cm})^{* \star *}$ & & $10.5 \sim 12$ & $6.5 \sim 12$ & $3 \sim 5$ \\
\hline \multirow[t]{3}{*}{1.5} & Sand B & Alumina & $0 \sim 8$ & $0.8 \sim 2$ & $0.5 \sim 1$ \\
\hline & $(20 \sim 30 \mathrm{~cm})$ & & $8 \sim 9$ & $6 \sim 13$ & $4 \sim 6$ \\
\hline & & & $9 \sim 12$ & $10 \sim 16$ & $5 \sim 9$ \\
\hline \multirow[t]{3}{*}{$1-6$} & Sand A & Sand A & $0 \sim 9$ & $10 \sim 14$ & $4 \sim 7$ \\
\hline & $(15 \sim 25 \mathrm{~cm})$ & & $9 \sim 11$ & $11 \sim 18$ & $4 \sim 7$ \\
\hline & & & $11 \sim 15$ & $20 \sim 23$ & $9 \sim 11$ \\
\hline \multirow[t]{2}{*}{1.7} & Sand A & Sand A & $0 \sim 7$ & $9 \sim 14$ & $3.5 \sim 6.5$ \\
\hline & $(20 \sim 30 \mathrm{~cm})$ & & $7 \sim 12$ & $15 \sim 18$ & $6.5 \sim 10$ \\
\hline \multirow[t]{3}{*}{$1-8$} & Sand B & Sand A & $0 \sim 8$ & $7 \sim 10$ & $3.5 \sim 5.5$ \\
\hline & $(20 \sim 30 \mathrm{~cm})$ & & $8 \sim 9$ & $16 \sim 28$ & $6.5 \sim 11$ \\
\hline & & & $9 \sim 12$ & $30 \sim 33$ & $12.5 \sim 15$ \\
\hline \multirow[t]{3}{*}{$1 \cdot 9$} & Mixture layer & Sand A & $0 \sim 5$ & $5.5 \sim 9$ & $3.5 \sim 7$ \\
\hline & $(20 \sim 30 \mathrm{~cm})$ & & $5 \sim 6$ & $10 \sim 17$ & $7 \sim 12.5$ \\
\hline & & & $6 \sim 12$ & $50 \sim 90$ & $22 \sim 55$ \\
\hline \multirow[t]{2}{*}{$\overline{1-10}$} & Sand A, Chimney & Sand A & $0 \sim 6$ & $5 \sim 9$ & $3 \sim 6.5$ \\
\hline & (width,10cm) & & $6 \sim 12$ & $12 \sim 17$ & $6 \sim 9$ \\
\hline \multirow[t]{3}{*}{$1 \cdot 11$} & Sand A, Chimney & Sand A & $0 \sim 7$ & $5 \sim 9$ & $3 \sim 5.5$ \\
\hline & (width,5cm) & & $7 \sim 8$ & $10 \sim 15$ & $6 \sim 9$ \\
\hline & & & $8 \sim 12$ & $15 \sim 19$ & $7 \sim 12$ \\
\hline \multirow[t]{3}{*}{$1-12$} & Sand B, Chimney & Sand $\mathrm{A}$ & $0 \sim 6.5$ & $4 \sim 7$ & $1.5 \sim 3.5$ \\
\hline & (width, $10 \mathrm{~cm}$ ) & & $6.5 \sim 8$ & $9 \sim 18$ & $4.5 \sim 8$ \\
\hline & & & $8 \sim 12$ & $18 \sim 24$ & $9 \sim 13$ \\
\hline
\end{tabular}

"gas inject velocity $U_{b}=40 \mathrm{~m} / \mathrm{s}$ except for Run $1 \cdot 1$

${ }^{\star *}$ Alumina sphere, ${ }^{\star * *}$ charged position : distance from top of the equipment

期とスリップ距離を指標として Table 3にホした。本実験 の灯頂変位の変動は比較的長周期かつ大きな振幅の範囲で 測定されたため変動のスペクトル解析等を行わずとも上記 の指標で変動特性の概略を評価できるものと考えた。

$3 \cdot 1 \cdot 1$ 水平砂層を装入しない時の粒子挙動 (Run 1-1,

Run 1-2, Run 1-3)

（1）ガス流れの影響

Table 3の Run 1-1は羽口からガスを供給しない時の灯頂 
変位の変動特性を示す。ごく短い周期で運動停止とスリッ プを繰り返す，粒子重力流動の基本運動が示されている。 Run 1-2はガスを流した場合 $\left(U_{B}=40 \mathrm{~m} / \mathrm{s}\right)$ であり，Run 1-1に 比べて端吊/スリップの周期およびスリップ距離共に大き く増加しており，灯頂降下運動の不連続性が増大している ことが明睽に示されている。

\section{（2）炉芯のガス透過性の影響}

羽口速度はすべての実験で $U_{B}=40 \mathrm{~m} / \mathrm{s}$ であるが，特に炉 下部の局所ガス速度は炉芯の空間率など炉芯充填構造の影 響を受ける。炉芯粒子の種類はRun 1-2ではアルミナ粒子， Run 1-3では砂Aである。炉頂に置ける棚吊／スリップの 周期，レースウエイガス静圧 (タップB1)，粒子壁面応力 の時間的変化を Fig. 2に示した。レーザー変位の水平部分 は棚吊のため灯頂粒子が静止している期間を示し，変位の 突然の增加はスリップによる粒子降下を示す。ベリー部粒 子壁面応力（Fig. 1，Cの個所）はスリップの瞬間に減少し 棚吊の瞬間に增加することが砂 A炉芯の Fig. 2(b)に示され ている。この現象はスリップによるレースウエイへの粒子 流入時では空間率の大きい流動状態が, 棚吊ではアーチが 粒子荷重を支える，応力の受働状態状態が形成されること に，それぞれ対応するものと思われる。

ガス静圧はレースウエイの膨張を伴う棚吊の間は增加す るが，スリップで急激に減少する場合(Fig. 2(a)) と Fig. 2(b) のように最大静圧值を迎えた後に減少してスリップに至る 場合がある。Fig. 2(b)ではレースウエイが膨張し，静圧 タップB1が空隙率の大きい（通気性の良い）レースウエ 亿内に取り込まれた時から静圧は減少した。

Fig. 2に示されるように棚吊/スリップの周期とスリップ
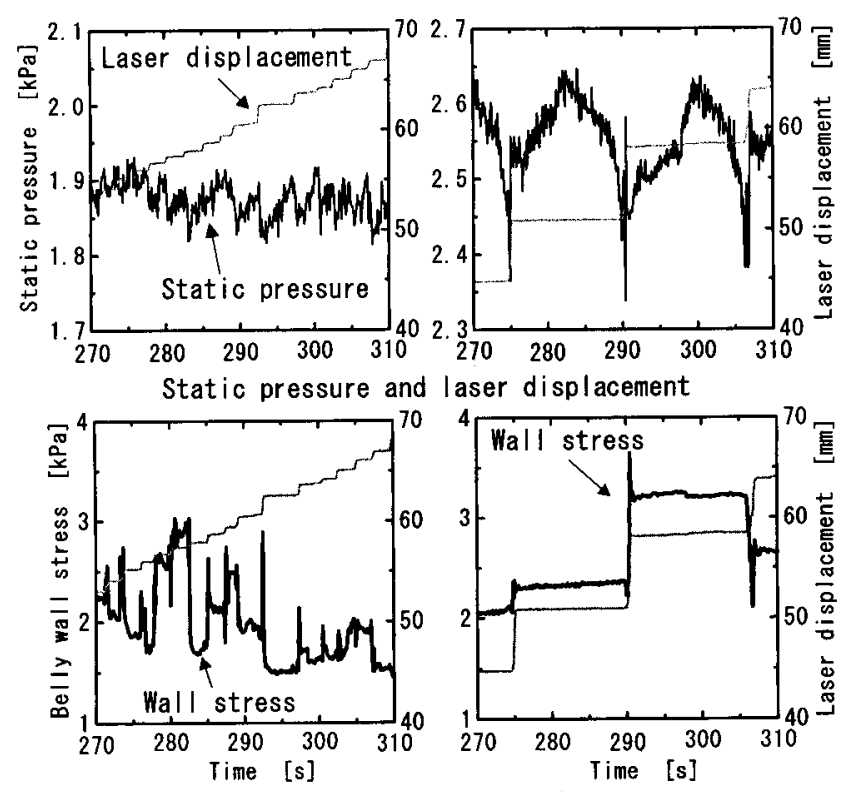

Solid stress and

(a) Deadman with alumina particle (Run 1-2)

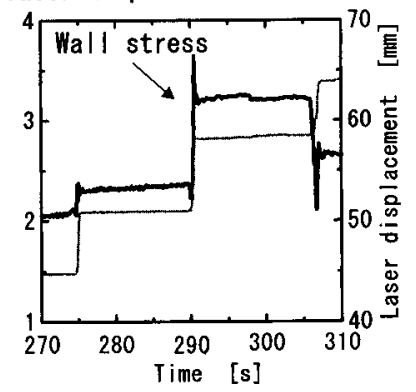

(b) Deadman with sand $A$ (Run 1-3)

Fig. 2. Effect of deadman material on discontinuous solid motion and static pressure.

距離は砂 A炉芯としたRun 1-3で顕著に增加している。 Table 3によると, Run 1-3ではRun 1-2に比べて周期は5 6 倍，スリップ距離は7 10倍大きい。固体流れの不連続性 が増加する理由は, 羽口ガスが通気抵抗の大きい砂の炉芯 内部へと透過するよりも垂直方向に透過する方がより容易 であること、これによりレースウエイ上方の粒子ブロック の固体荷重を支持するほどに流体抗力が增加したためと考 えられる。B1(Fig. 1)で測定される静压はFig.2に示される ようにRun 1-2に比べてRun 1-3では相当大きい值となって いる。このことは砂 A炉芯の Run 1-3ではガスの周辺流化 （レースウエイ直上での垂直流化）によるガス圧力損失 （流体抗力）の増大を意味する。

$3 \cdot 1 \cdot 2$ 水平砂層を抻入した時の粒子挙動

（1）アルミナ炉芯の場合

水平に充填された砂層の経時変化 (Run 1-4)を Fig. 3に示 した。Fig. 4は540 720秒における棚吊/スリップの周期 とスリップ距離を, 砂層非装入の Run 1-2 と比較して示し たものである。Fig. 4よりRun 1-4に抢ける不連続性は操作 開始後 630秒（10.5 分）まではRun 1-2のそれとほぼ同じで あるが，それ以降ではRun 1-4の不連続性が顕著になって

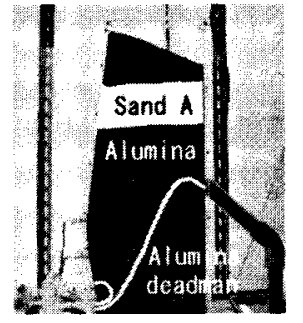

(a) Initial state

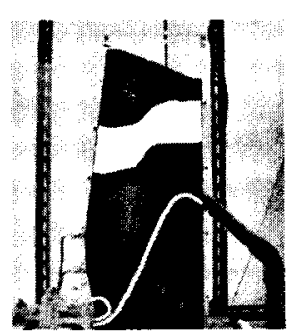

(b) $180 \mathrm{~s}$

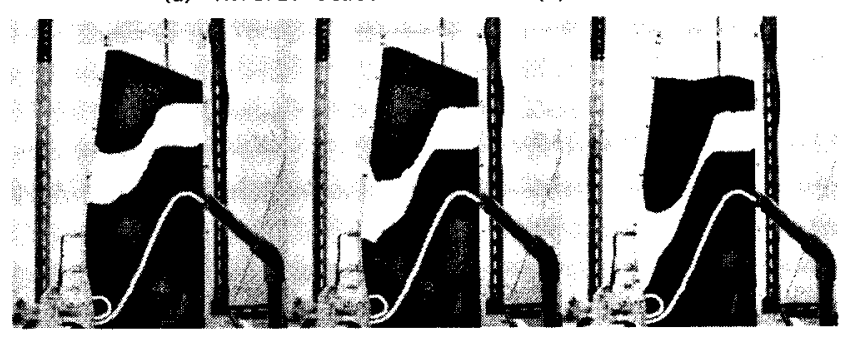

(c) $360 \mathrm{~s}$

(d) $540 \mathrm{~s}$

(e) $720 \mathrm{~s}$ (Run out)

Fig. 3. Flow pattern of horizontally charged sand A layer (Run 1-4).

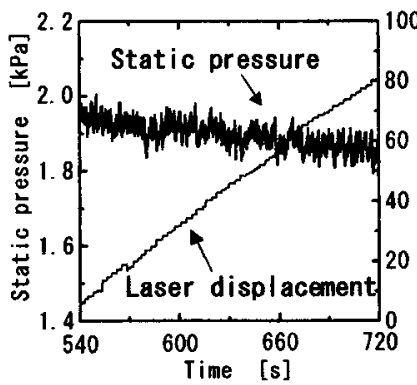

(a) Without charge of sand layer (Run 1-2)

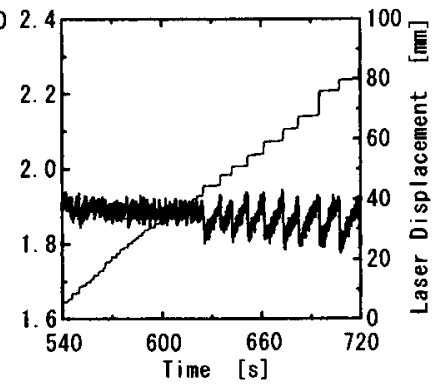

(b) Horizontal charge of sand A layer (Run 1-4)
Fig. 4. Effect of sand layer on discontinuous solid motion and static pressure (deadman: Alumina particle). 
いる。Fig. 30フローパターンから模擬融着带（砂層）は 630 秒以降，炉芯に極めて按近することが予想できる。

不連続挙動の発生の原因は一般に，(1)同一ガス流量を 維持する時は低通気性の砂層には強い流体抗力が働き，こ れによりレースウエイ上に作用する粒子荷重（重力流動の ポテンシャル）が減少して，レースウエイへ粒子を押し出 す効果が小さくなる，さらに，(2)ファンネルフロ一流路 の大部分が擬停滞域（炉芯上方に発達して粒子があたかも 停滞しているような領域 6.7.99) によって支配されるまでに 至った時は，粒子のレースウエイへのスムーズな流れが極 度に阻害される，ことによりレースウエイ膨張が進行する ためと考えられる。

水平砂層に砂 Bを用いた場合については，Table $3 の$ Run 1-5（砂 B）とRun 1-4（砂 A）の比較をすると棚吊 / スリップの周期とスリップ距離に関しては，両者に大きな

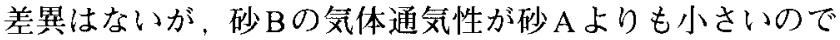
不連続性はRun 1-5のほうが若干大きい。

\section{（2）砂炉芯の場合}

Run 1-6 と Run 1-3 比較する。Fig. 5 はRun 1-6のフローパ ターンと不連続性を示す。 Table 3より，棚吊/スリップの 周期およびスリップ距離を指標とする不連続性の度合い は，Run 1-6の操作開始後 9 分（Fig. 5で540秒）までは Run 1-3（水平砂層なし）と比べて大きな差はないことが 判る。その時間以降, 不連続性は徐々に大きくなり, 3·1·1で述べた砂炉芯による周辺流化と上記( 1 )で示した 理由により，かなり大きな不連続性が現れている。12分 以降，レースウエイは砂によって完全に置換され極めて重 大な不連続性が現れる事態となった。また，Run1-6の不 連続性はRun 1-4（アルミナ炉芯）より大きい(Table 3)が これは先に述心゙た炉芯粒子の通気性の違いによる。粒子径 のより小さい砂 B層を用いたRun 1-8ではRun 1-6と比べて より大きな不連続性を示しており，特にレースウエイが砂 Bで置換された後では特に顕著である。この状況でのレー スウエイの挙動をFig. 6に示した。砂はスラッギング状態 で流動化しており，かつ砂はレースウエイ周囲にも存在す
る。館ら ${ }^{5}$ は粗コークスと粉コークスの混合物を用いた熱 間モデルで燃焼ゾーンの周り上方に広がる粉コークスの蓄 積層を観察し，この粉コークス層が高炉における不安定挙 動の原因と仮定しているが，本実験結果はこれを裏付ける 結果となっている。

(3) 砂混合層 $(\mathrm{A}+\mathrm{C})$ の水平装入

砂層のガス通気性をより低くした実験である。結果は Run 1-9に示す。砂混合層がシャフト上部にあるときは砂 単層の場合と比べて不連続挙動には顕著な差異は見られな かった。しかし，Fig. 7に示すように，砂Cがレースウエ イに流入して砂Cの薄い層がレースウエイと炉芯の境界に 形成された時蝴吊時間が最大 90 秒，炉頂スリップ距離 $50 \mathrm{~mm}$ という単層砂 $\mathrm{A}$ や単層砂 $\mathrm{B}$ の場合には見られなかっ た極めて大きな不連続性が観察された。炉頂変位と静圧の 変化はレースウエイの膨張と対応している。図で白く見え る物質が砂Cである。

結果として，レースウエイ周囲での細粒薄層の形成や流 動化もガスの周辺流化を促し, 固体の不連続運動の重要な

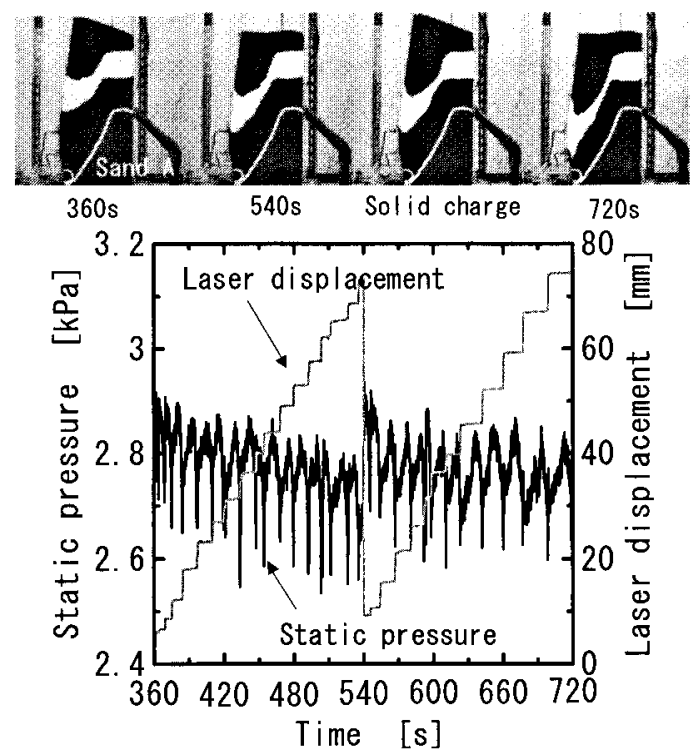

Fig. 5. Change of flow pattern and discontinuity with time (Deadman: sand A, Run 1-6)

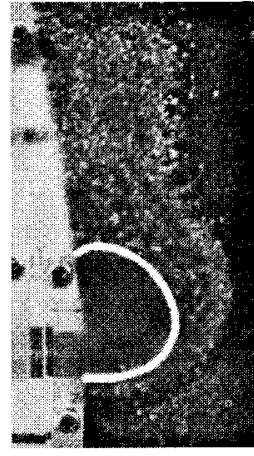

652

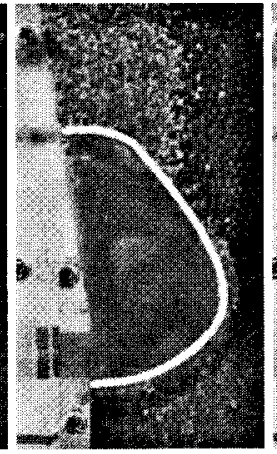

676

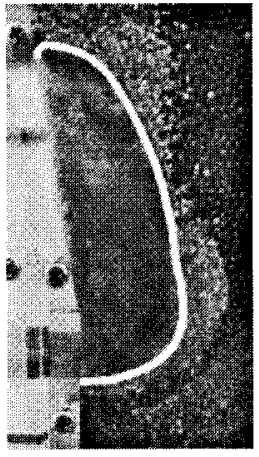

683

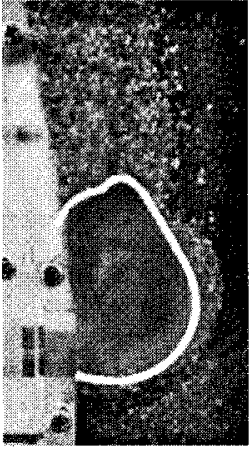

688

Time [s]

Fig. 6. Change of raceway size with time (Run 1-8, sand B layer). 
因子になることが示された。

\section{(4) チム二ー効果}

Table 3の Run 1-10 Run 1-12にチムニーを設定した場合 の結果が示されている。Fig. 8にRun1-10とRun1-7の フローパターンと不連続挙動を比較して示した。図より棚 吊/スリップの周期及びこれと連動する静圧変化の周期， さらにスリップ距離はRun 1-10のほうが小さくチムニー効 果により不連続性が減少することが明らかである。Fig. 8(a)と比較して (b)のガス静压が小さい。従って，よりス ムーズな固体流れが得られたのは炉右側の垂直壁近傍で高

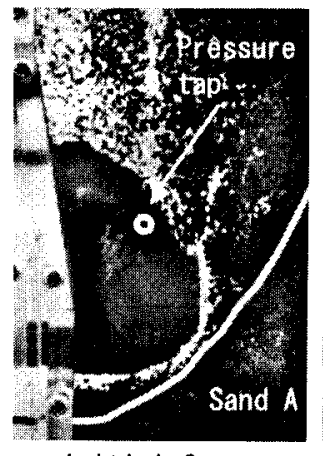

Initial form

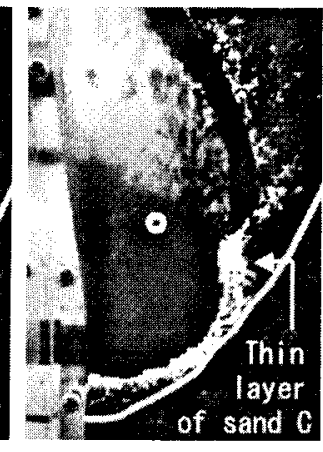

Col lapse

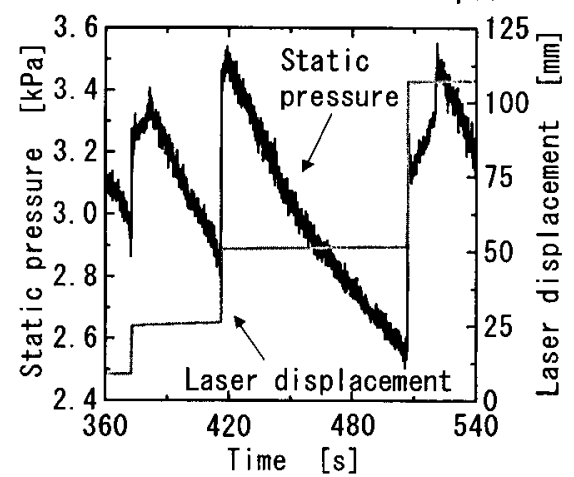

Fig. 7. Correspondence between raceway size and discontinuity (Run 1-9).
いガス透過性が確保された結果と考えることができる。千 ムニーのサイズの影響は実験の範囲では顕著でなかった (Run 1-10, Run 1-11)。

\section{（5）ファンネルフロー流路の幅と不連続性}

先に議論した模擬融着帯と炉芯表面間の距離が不連続挙 動に与える影響をFig. 9にまとめた。罒に执いて「レース ウエイから砂層の距離」は羽口と砂層の各々最下端の間の 距離として定義されている。罒は模擬融着茾が降下して， 羽口との距離がある限界の距離より小さくなると不連続性 が大きくなることを示しており，高炉の試験操作 ${ }^{1.2}$ で得 られた知見と対応している。擬似融着带に砂 $\mathrm{B}$ 層を用いた Fig. 9(b)でも Run 1-12（チムニー）のほうが棚吊/スリップ の周期がRun 1-8より短く，チムニー効果の存在が示され ている。

$3 \cdot 1 \cdot 3$ 羽口ガス周辺流化の指標ーモデルによる評価

羽口ガスの周辺流化の指標をレースウエイト方でアーチ の形成を仮定したモデル ${ }^{10)}$ から評価した。(垂直流量/全流 入ガス流量） $=\eta$ で定義した周辺流化の指標值は砂層（擬

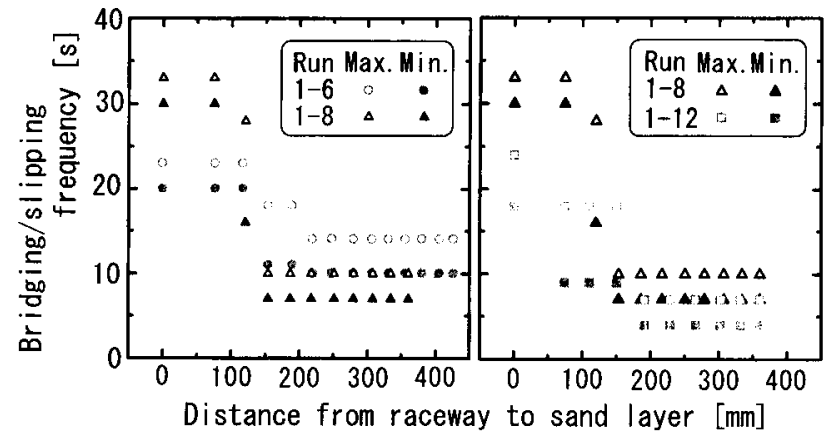

(a) Run 1-6 and Run 1-8 (b) Chimney effect

(Run 1-8 and Run 1-12)

Fig. 9. Effect of distance between raceway and sand layer on bridging/slipping frequency.

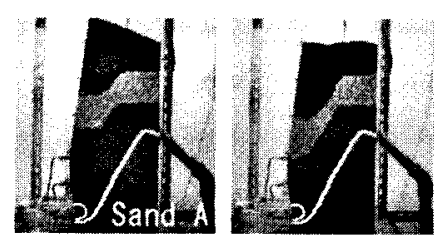

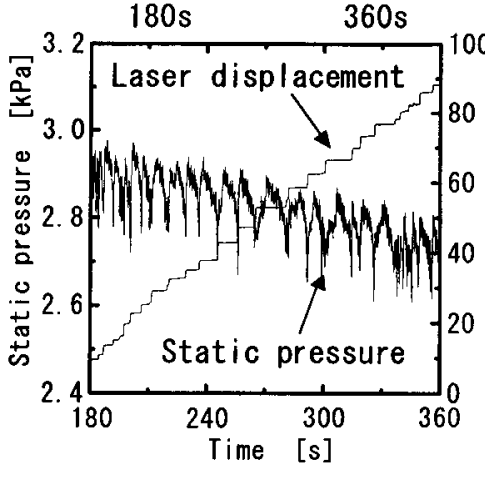

(a) Run 1-7

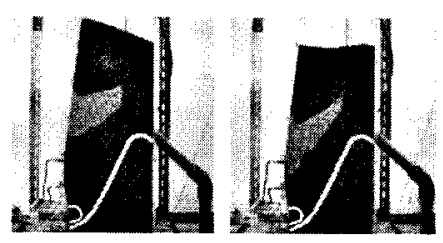

$180 \mathrm{~s}$

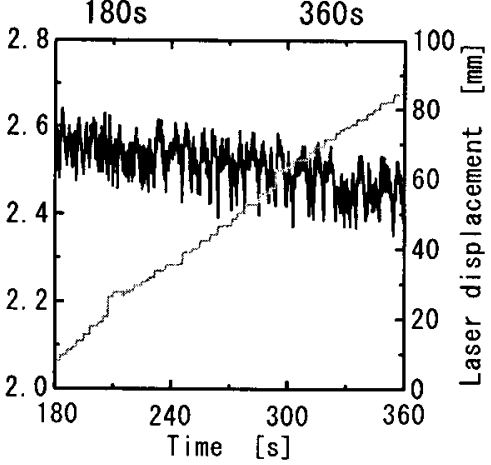

(b) Run 1-10

Fig. 8. Chimney effect with sand $B$ layer. 
似融着帯）無しのアルミナ粒子のみの場合は $\eta=0.5$ である が，一方，砂層装入実験では砂層が炉芯表面に接近するに つれて周辺流化は発達し，砂層がレースウエイに流入を始 めると周辺流化は最大に達し， $\eta=0.9$ となった。棚吊・崩 壤挙動はレースウエイガスの周辺流化指標 $\eta$ と密接な関係 にあることがわかった。

\section{$3 \cdot 2$ 実験 2}

実験条件と粉コークスの挙動を Table 4にまとめた。粉 コークスの挙動はcrack (龟裂), flooding (フラディング), bridging (棚吊)，bridging/slipping（棚吊・スリップ）の用 語で記述されている。Crack（亀裂）は粉コークス層の下 端に亀裂の空間が形成される場合であり，粉コークス層が 亀裂の崩壊・再生成を伴って降下寸る場合も含む。Flooding（フラディング）は粉コークス粒子がガスにより充填 層空間を通過して上方へ輸送され充填層内へ拡散する状況 を表す。粉コークス粒子が祖粒と共に降下しながら上方拡 散する場合も含む。なお，表中，'descent'は粒子の降下運 動表表す。

\section{$3 \cdot 2 \cdot 1$ ガス流れの影響}

Table 4から明らかなように龟裂または棚吊・崩壊は一般 に, シャフトの通気抵抗層（砂 B）の存在や炉芯形成粒子 の種類によらず, $U_{B}=35 \mathrm{~m} / \mathrm{s}$ 以上の高いガス速度の場合に 観察され，時間の経過と共にフラディングが出現した。 $U_{B}=31 \mathrm{~m} / \mathrm{s}$ および $U_{B}=28 \mathrm{~m} / \mathrm{s}$ では棚吊は現れずフラディン グを伴う降下運動が主流であった。2・2節で述べたように

Table 4. Result of Experiment 2.

\begin{tabular}{|c|c|c|c|c|c|c|}
\hline $\begin{array}{l}\text { Run } \\
\text { No. }\end{array}$ & $\begin{array}{c}\text { Thick- } \\
\text { ness } \\
l \\
{[\mathrm{~mm}]}\end{array}$ & $\begin{array}{c}\text { Width } \\
\\
W \\
{[\mathrm{~mm}]}\end{array}$ & $\begin{array}{c}\text { Gas } \\
\text { velocity } \\
U_{B} \\
{[\mathrm{~m} / \mathrm{s}]}\end{array}$ & $\begin{array}{l}\text { Deadman } \\
\text { material }\end{array}$ & $\begin{array}{l}\text { Sand B } \\
\text { in shaft }\end{array}$ & Fines behavior \\
\hline $2 \cdot 1$ & 5 & 80 & 35 & Alumina & non & crack $-\mathrm{s}^{* *} /$ flooding \\
\hline $2 \cdot 2$ & 15 & 80 & 35 & Alumina & non & crack-s/descent/flooding \\
\hline $2-3$ & 15 & 160 & 35 & Alumina & non & crack/descent/flooding \\
\hline $2 \cdot 4$ & 15 & full span & 35 & Alumina & non & bridging \\
\hline $2 \cdot 5^{* * *}$ & 15 & $($ full span)/2 & 35 & Alumina & non & crack $\cdot \mathrm{s} /$ descent/flooding \\
\hline $2-6$ & 5 & 80 & 28 & Alumina & non & descent/flooding \\
\hline $2 \cdot 7$ & 5 & 160 & 28 & Alumina & non & $\operatorname{crack} /$ descent \\
\hline $2 \cdot 8$ & 5 & 80 & 31 & Alumina & non & descent/flooding \\
\hline $2-9$ & 5 & 160 & 31 & Alumina & non & descent/flooding \\
\hline $2 \cdot 10$ & 5 & full span & 35 & Alumina & non & flooding \\
\hline $2 \cdot 11$ & 15 & 160 & 35 & Alumina & yes & bridging/slipping \\
\hline $2-12$ & 15 & 80 & 35 & Sand A & non & bridging/slipping \\
\hline $2-13$ & 15 & 80 & 31 & Sand A & non & descent/flooding \\
\hline $2 \cdot 14$ & 15 & 80 & 31 & Sand A & yes & descent/flooding \\
\hline $2-15$ & 5 & 80 & 35 & Sand A & non & flooding \\
\hline $2 \cdot 16$ & 5 & 80 & 31 & Sand A & non & descent/flooding \\
\hline $2 \cdot 17$ & 15 & 40 & 35 & Sand A & non & crack $\cdot$ s/descent/flooding \\
\hline $2 \cdot 18$ & 15 & 40 & 35 & Sand A & yes & crack/descent/flooding \\
\hline $2-19$ & 15 & 160 & 35 & Alumina & $\begin{array}{l}\text { yes, with } \\
\text { chimney }\end{array}$ & crack/flooding \\
\hline
\end{tabular}

"Three layers of Sand "Small crack,

***Fines layer was set at the position, (shaft height/4) on the belly top
$U_{B}=35 \mathrm{~m} / \mathrm{s}$ は, 規則立方充填構造から計算された，単一 コークス粉（細粒）が充填層空隙を上方に輸送される限界 速度である。このような条件下で多量のコークス粉が同時 にその空隙に集中した場合に棚吊が起こるものと考えられ る。龟裂あるいは棚吊が発生するための限界最小ガス速度 が存在し，前報8〉で示した方法によってこれを推定でき ることが確かめられた。

$3 \cdot 2 \cdot 2$ 粉コークス層の厚みに影響

$U_{B}=35 \mathrm{~m} / \mathrm{s}$ の場合について, Table 4 の Run 2-12 と Run 215 （共に㻏芯粒子：砂 $\mathrm{A}$, 層幅 $w=80 \mathrm{~mm}$ ）およびRun 2-4 とRun 2-10（共に炉芯粒子：アルミナ球， $w=$ フルスパン） を比較して，粉コークス層の厚みlが固体流れに与える影 響を検討する。棚吊・スリップは粉コーク層の層厚 $l=15 \mathrm{~mm}$ の時に発生可能であり, 一方 $l=5 \mathrm{~mm}$ のように層 厚が小さい時は粉コークスの運動はフラディングによって 支配されている。このことより，龟裂または棚吊・スリッ プが発生するためにはある限界の最小厚み以上の蓄積が必 要であることが示唆される(最小蓄積層厚み)。

\section{$3 \cdot 2 \cdot 3$ 粉コークス層の幅の影響}

Fig.10（Run 2-2, 2-3及び 2-4：アルミナ粒子灯芯）によ り不連続挙動に与えるコークス船の幅wの影響を検討す る。亀裂や棚吊は幅 $w$ 大さりほぼ発達しやすかった。通 気抵抗の大きい粉コークス層の存在によりガス上昇流れの 方向が右壁側（垂直壁側）に縮流したことがこの一因と考 えられる。ガス流量が同一である限りこのガス流路の収縮 （縮流）は高圧力損失を生み出すことになる。従って， コークス層直下の静圧の増加, 即ち流体抗力が增加するた め龟裂や棚吊を引き起こすのであろう。Run 2-3では最大 $8 \mathrm{~mm}$ の高さの亀裂が観察された。Run 2-4に示されるよう に，もしも粉コークス層がフルスパンに渡って蓄積される 場合は縮流の場合よりももっと大きな流体抗力が生じ，こ れが粉コークス層上に作用する粒子荷重に打ち勝つため棚
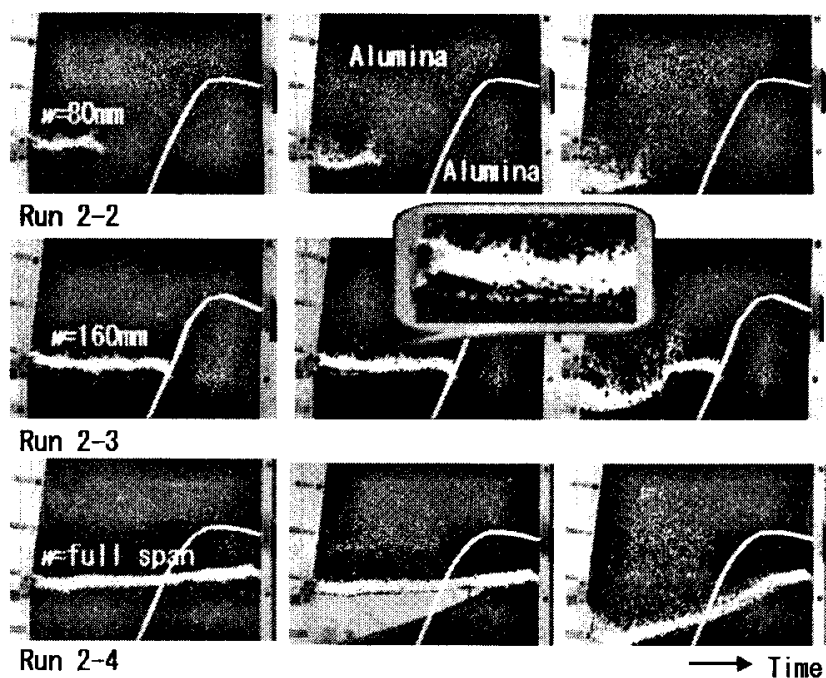

Fig. 10. Effect of fine coke layer's width on discontinuous motion (Runs 2-2, 2-3 and 2-4). 


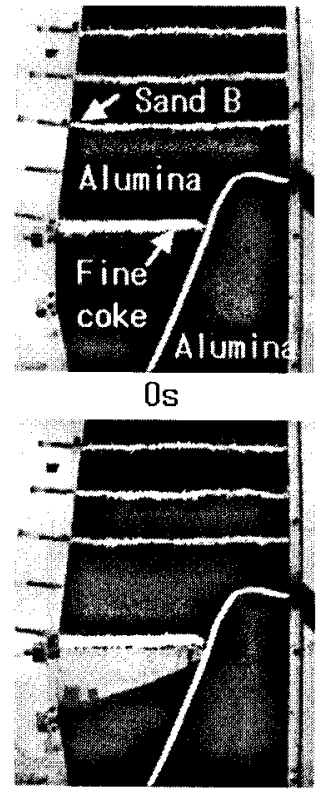

$184 \mathrm{~s}$

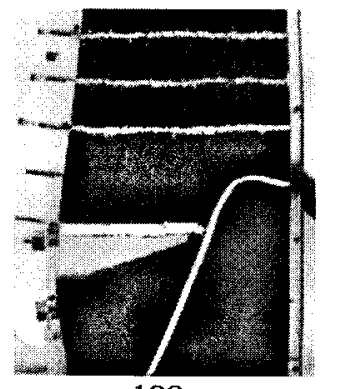

$120 \mathrm{~s}$

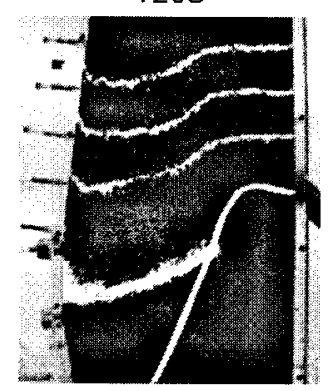

$185 \mathrm{~s}$
Fig. 11. Flow pattern with three layers of sand B charged in shaft (Run 2-11).

吊が発生したものと考えられる。しかし，仮にフルスパン 蓄積が可能な場合でも，その厚みlが小さい時は，3·2·2. 節で論じたように，細粒（粉コークス）は上方に拡散す る。

\section{$3 \cdot 2 \cdot 4$ シャフト上部に装入した砂 $\mathrm{B}$ 層（低通気性粒子） の影響}

Run 2-3 と低通気性の砂層を三層装入したRun 2-11を比 較しよう。Run 2-11のフローパターンを Fig.11に示す。 Fig.10の Run2-3では粉コークス層は俥裂を形成しながら， かつガス流れによる微粉の桩散を伴いながら降下してい る。一方，低通気性の砂 Bの三層装入はFig.11のような大 きな棚吊を引き起こしている。低通気性の砂層の存在によ り発生した大きな流体抗力がシャフト部の粒子荷重を支え る結果, 粉コークス層に作用する粒子荷重は減少する。 Fig.11の棚吊は重力流動の原動力である粒子荷重の減少に よるものと考えられる。シャフト部の通気性の低下は固体 流れの不安定性を引き起こすことが示された。

Fig.12はシャフト部に砂 Bを装入しないRun 2-3 (Fig.10) における静圧とレーザー変位の経時変化を示す。初期にお いて静压は初期静止充填状態から龟裂空間を含むより大き な動的空陌状態へ変化するにつれて急激に低下したが，そ れ以降は炉頂表面の降下（ヘッドの減少に）より静圧も 徐々に低下した。レーザー変位の変化はあたかも線形のよ うに見えるがRun 2-3 (Fig.10)の龟裂の発生とスリップに対 応する, 炉頂変位の階段状の変化が測定されている10)。さ て，180秒から360秒の間で静圧の増加を伴う重大な棚吊 が発生し，その後突然のスリップと静圧の減少が起きてい る。120秒という長期の棚吊の後 $60 \mathrm{~mm}$ のスリップが炉頂 で観察されている。これはコークス粉のレースウエイへの

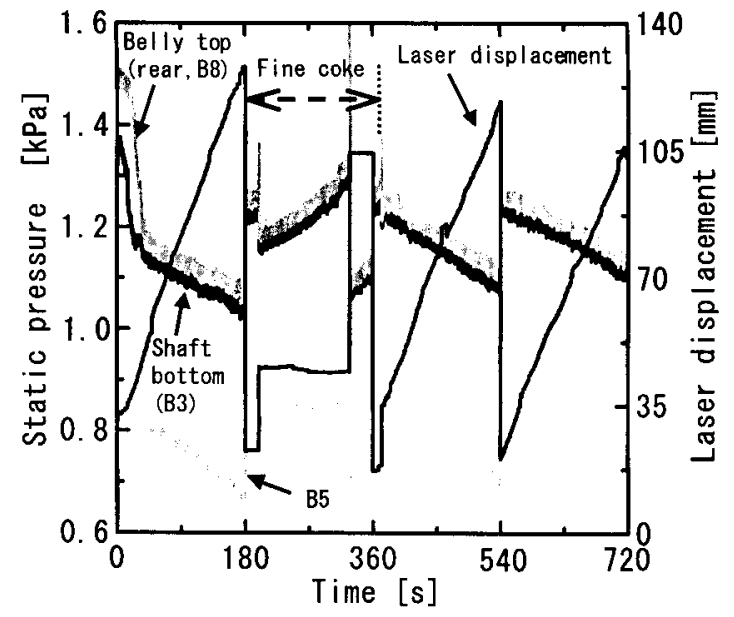

Fig. 12. Change of discontinuity with time (Run 2-3).

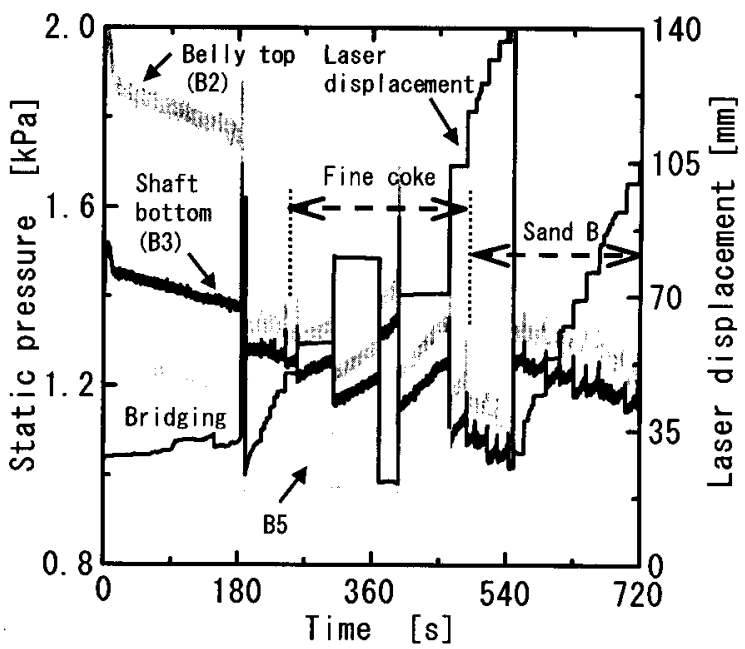

Fig. 13. Change of discontinuity with time (Fig. 14, Run 2-11).

流入とレースウエイ境界での低通気性のコークス粉薄層の 形成が原因である(このメカニズムについては奏験 1 ， $3 \cdot 1 \cdot 2$ 節で述べた)。およそ時刻 360 秒以降は，レースウ エイの粉コークスが排出されコークス粉薄層も消滅してい るので，いかなる不連続性も観察されていない。次に， Run 2-11 (Fig.11)の静圧とレーザー変位の経時変化を Fig.13 に示した。図は三段階の粒子挙動からなっている。第 1 段 階は時刻 $0 \sim 184$ 秒でありべリ一上部からシャフト下端で

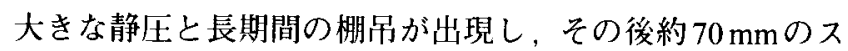
リップが観察されている。第2段階はコークス粉のレース ウエイへの流入期間での不連続挙動である。最後の段階は 炉下部まで降下してきた砂 $\mathrm{B}$ 層のレースウエイへの流入の 影響が現れる期間である。この最後の期間ではコークス粉 の流入時よりも不連続性は小さい。レースウエイへ流入す る粒子の粒子径が小さいほど不連続性は増大することがわ かった。

低通気性の砂 B層を装入した時は, 粉コークス層の幅が

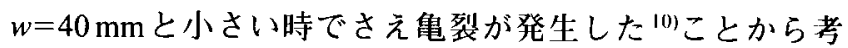




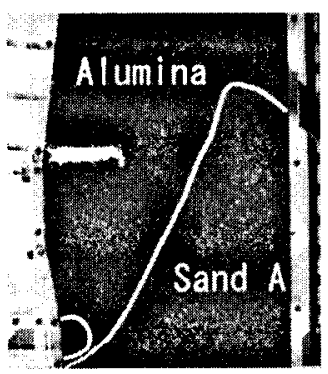

0s

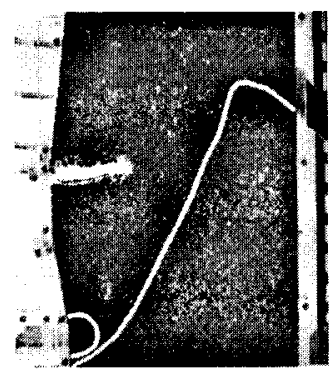

$45 s$

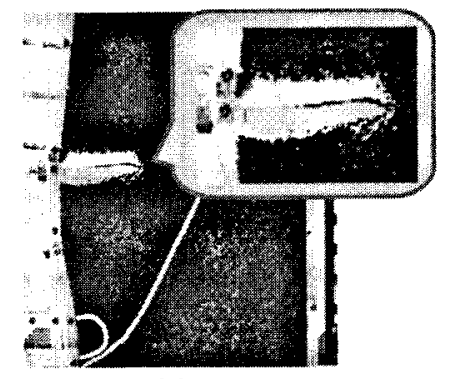

$44 \mathrm{~s}$

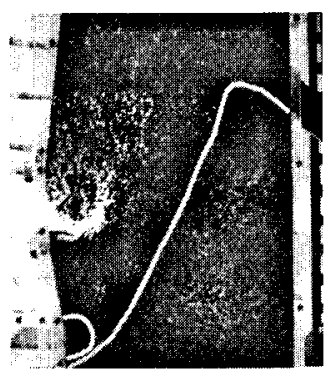

$135 \mathrm{~s}$
Fig. 14. Flow pattern with sand A deadman (Run 2-12).

えると、シャフト部における低通気性砂層の存在の影響は 相当大きいものと思われる。

垂直壁から10 cmだけ砂 Bを装入しない領域を作り，砂 B不完全三層装入にてチムニー効果を調べた(Run 2-19)。 Run2-19はRun2-11 (Fig.11)と同じ実験条件で行われ, 結 果はTable 4に示されている。ここでも Fig.11のような棚 闹ノスリップは発生せずチムニー効果が確認できた。

\section{$3 \cdot 2 \cdot 5$ 灯芯粒子の通気性の影響}

最後に，シャフトには低通気性の仯層を装入しない場合 において, Table 4の Run 2-2とRun 2-12の比較を行い，粉 コークス蓄積洔の不連続性に及ぼす炉芯粒子の通気性の影 響を検討した。アルミナ炬芯のRun 2-2では粉コークス層 は微少の亀裂・スリップとフラディングを伴って降下し た。一方，砂A炉芯としたときのRun2-12のフローパター ン，静压とレーザー変位の経時変化をそれぞれ Figs. 14, 15 に示す。棚吊が明確に観察され(Fig.14)，時刻45秒に約 $10 \mathrm{~mm}$ の炉頂スリップが示されている(Fig.15)。低通気性 の炉芯では，奉娩 1 と同様，ガスの周辺流化が促進され粉 コークス粒子による不連続挙動にも重大な影響を及ぼすこ とが確認された。

\section{4. 結論}

高邩の低還元材比操業における棚吊・スリップを伴う固 体の不发定運動を支配する因子を見出すための実験的研究 を行った。低通気性の融着帯を砂層で模擬した実験では全 羽山ガス流量に対する周辺化流の割合が固体とガス静圧の 不連続挙動に大きな影響を与えることが判った。周辺化流 の割合は以下の条件により増加した。1)炉志の通気性の低

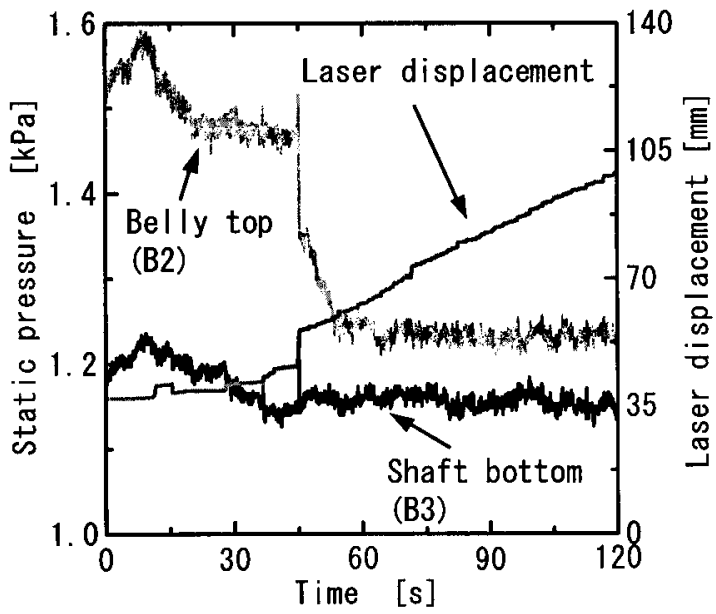

Fig. 15. Change of discontinuity with time (Run 2-12).

下，2)炉芯表面への模擬融着帯の接近，3)レースウエイへ の細粒の流入。上記 2)については，模擬融着带がある限 界の位置から更に低下すると不連続性が急激に増加するこ とが想められた。この条件は実炉で融着带が炉芯擬停滞域 近傍まで降下移動した時と対応するであろう。シャフト下 端レベルに蓄䅡した粉コークス層も不連続挙動を引き起こ した。棚吊を引き起こす限界ガス速度，限界蓄積層厚みが 存在し, この他, 蓄積層の幅が関与することが示唆された シャフト部低通気性粒子層の存在は蓄積粉コークス層の棚 吊を誘引するほどの重大な影響を与えた。気体透過性の良 いチムニ一領域を炉中心部に設けると全ての場合において 粒子挙動の不連続性を減少させることが出来た。

（株）神戸製鋼所，松井良行氏および新日本製鐵（株）， 松崎㡭六氏には有益な討論を頂いた。付して謝意を表しま す。

\section{記 号}

\footnotetext{
$d_{p}$ : Particle diameter $(\mathrm{mm})$

$f_{1}$ : Coefficient of Erugun's eqation defined in Table $1\left(\mathrm{~N} \mathrm{~s} / \mathrm{m}^{4}\right)$

$f_{2}:$ Coefficient of Erugun's eqation defined in Table $1\left(\mathrm{~N} \mathrm{~s}^{2} / \mathrm{m}^{5}\right)$

$F_{D} \quad$ : Fluid drag on a single particle $(\mathrm{N})$

$F_{E} \quad$ : External force exerted by a single particle (N)

$l$ : Thickness of fine coke layer ( $\mathrm{mm})$

$u_{f} \quad$ : Superficial velocity at shaft bottom level $(\mathrm{m} / \mathrm{s})$

$u_{m j}:$ Minimum fluidizing velocity $(\mathrm{m} / \mathrm{s})$

$U_{B}:$ Blast velocity $(\mathrm{m} / \mathrm{s})$

Us : Solid descending velocity at top of apparatus $(\mathrm{m} / \mathrm{min})$

$w \quad:$ Width of fine coke layer $(\mathrm{mm})$

$W_{R}$ : Solid discharging rate $(\mathrm{kg} / \mathrm{min})$

$W_{S} \quad$ : Sub-discharging rate $(\mathrm{kg} / \mathrm{min})$

$\varepsilon \quad$ : Void fraction of particle bed $(-)$

: Index of peripheral flow (-)

: Angle of repose of particles (deg)

: Bulk density of particle bed $\left(\mathrm{kg} / \mathrm{m}^{3}\right)$

: Density of particle $\left(\mathrm{kg} / \mathrm{m}^{3}\right)$

$\varphi$ : Sphericity, defined by dividing the surface area of a sphere of the same volume as the particle by the surface area of the particle. $\varphi=1$ for sphere (-)
} 


\section{文献}

1) Y.Togino, M.Tateoka, M.Sugata, K.Yamaguchi, S.Kume, K.Yamaguchi and I.Abe: Tetsu-to-Hagané, 65 (1979), 1553.

2 ) S.Kajikawa, R.Yamamoto, R.Nakajima, S.Kishimoto and T.Fukushima: Tetsu-to-Hagané, 68 (1982), 2361.

3 ) H.Kawata, S.Kishimoto, A.Maki, Y.Saijyo, H.Wakai and K. Yamamoto: Tetsu-to-Hagané, 79 (1993), 75.

4 ) K.Kojima, T.Nisi, T.Yamaguchi, H.Nakama and S.Ida: Tetsu-toHagané, 62 (1976), 570.
5 ) M.Tate, Y.Kuwano, K.Suzuki, T.Chang, H.Go and M.Matsuzaki: Tetsu-to-Hagané, 62 (1976), 495.

6 ) H.Takahashi and N.Komatsu: ISIJ Int., 33 (1993), 655.

7 ) H.Takahashi, M.Tanno and J.Katayama: ISIJ Int., 36 (1996), 1354

8 ) H.Kawai, H.Takahashi and M.Ichida: ISIJ Int., 45 (2005), 1112.

9 ) H.Takahashi, K.Kushima and T.Takeuchi: ISIJ Int., 29 (1989), 117.

10) H.Takahashi, H.Kawai, M.Kobayashi and T.Fukui: ISIJ Int., 45 (2005), 1386 